\title{
Growth Potential and Profitability Analysis of Insurance Companies in the Republic of Serbia
}

\author{
Dragana Ikonić, Nina Arsić \\ Higher School of Professional Business Studies, Novi Sad, Republic of Serbia \\ Snežana Milošević \\ Economic and Trade High School, Senta, Republic of Serbia
}

\begin{abstract}
Economically developed countries hold much of its total wealth as financial savings, and they should faster experience higher rates of overall economic growth in the long run. Given the level of income made by economic entities and according to such correlation, their propensity to save can be generated. As a clear reflection of the development of the financial sector, insurance companies as financial intermediaries, through the mobilization of savings, contribute to the development of the entire financial sector. Analyzing the performance of insurance companies in Serbia, CARMEL method will be applied, which includes indicators for the presentation of quantitative criteria for the purpose of monitoring and analyzing the profitability of insurance companies consisting of a model that is the current methodology of the MMF. In addition to traditional financial instruments, derivative securities are traded in financial markets, promoting the development of financial markets, such as options, which are generators of potential growth of profitability. The aim of this paper is to show the growth potential of profitability in insurance companies, as well as decreasing risks which are connected to the business activities by the use of options.
\end{abstract}

Keywords: growth, profitability, insurance companies, options

\section{Growth Potential of Insurance Sector}

\section{The Development of Insurance Sector}

As far as modestly developed Serbia's insurance market is concerned, the premium from credit portfolio of insurance is insignificant because credit insurance is widespread among developed economies. The consequences of global financial crisis that are largely seen in our country are characterized by limited supply of capital, more expensive loans and decreased demand. With the present problem of getting receivables, it is clear that there are no signs of developing credit insurance sector in Serbia. From the perspective of financial markets, insurance companies and pension funds play the significant role as institutional investors in various securities. So with these

Dragana Ikonić, MA of Economics, Research Associate, Higher School of Professional Business Studies.

Nina Arsić, MA of Law, Research Associate, Higher School of Professional Business Studies.

Snežana Milošević, MA of Economics, Professor, Economic and Trade High School.

Correspondence concerning this article should be addressed to Dragana Ikonić, Vladimira Perica Valtera 4, 21000 Novi Sad, Republic of Serbia. E-mail: dragana_ikonic@yahoo.com. 
investments, they enable a significant and major increase in the liquidity of the market, as well as its overall performance. Sales of insurance policies to residents and businesses represent and create a long-term source of funds. These activities can be used to purchase long-term financial instruments — stocks and bonds, and short-term securities. The basic and the key form of insurance in developed countries, like the United States, is life insurance, while in less developed countries like the Republic of Serbia non-life property insurance is dominant.

The banking sector dominates the financial market in Serbia and it is followed by the insurance sector. It cannot be said about the fund industry which is just in the state of approximate trend. By the fact of delaying the development of domestic investors created a significant gap, which was filled with foreign portfolio investors. Regarding fund industry, the first and the crucial steps were made by voluntary private pension funds supervised by the National Bank of Serbia (Ikonić, Arsić, \& Milošević, 2011).

In the total assets of the financial sector in the year 2010, which amounted to 2,759 billion dinars, banks accounted for $91.8 \%$ and the insurance company with 4.2\%, as shown in Table 1 (National Bank of Serbia, 2010).

Table 1

The Share in the Total Financial Sector in Percent

\begin{tabular}{|c|c|c|c|c|c|c|c|c|c|c|c|c|}
\hline & \multicolumn{3}{|c|}{ Banks } & \multicolumn{3}{|c|}{ Leasing } & \multicolumn{3}{|c|}{ Insurance } & \multicolumn{3}{|c|}{ DPF } \\
\hline & 2008 & 2009 & 2010 & 2008 & 2009 & 2010 & 2008 & 2009 & 2010 & 2008 & 2009 & 2010 \\
\hline Total assets & 89.3 & 90.8 & 91.8 & 6.2 & 4.7 & 3.6 & 4.3 & 4.2 & 4.2 & 0.2 & 0.3 & 0.4 \\
\hline Capital & 93 & 92.1 & 92.5 & 1.4 & 1.9 & 1.5 & 5.6 & 6 & 6 & & & \\
\hline $\begin{array}{l}\text { Number of } \\
\text { employees }\end{array}$ & 72.2 & 72.5 & 71.8 & 1.2 & 1.1 & 1.1 & 26.2 & 25.9 & 26.8 & 0.5 & 0.4 & 0.3 \\
\hline
\end{tabular}

The structure and process of forming of financial institutions largely depend on the extent of development of financial market. Apart from legal limitations, there are other factors influencing the development of financial market, such as, political and economic conditions, currency stability, appropriate level of savings, etc.. Contemporary financial markets should have tendency to create business environment both for classic financial institutions and for new ones, which will offer a wide selection of financial services.

It can be stated that insurance sector is inadequately developed in Serbia. Not only is the level of its development below EU average, but there are also other indicators of development (the relationship between total premium and gross national product, and total premium per capita).

By influencing the rise in the price of risk and fall in the investment income, financial crisis causes the need for increasing the insurance premium. Figure 1 shows the development of insurance in some European countries, which can be analyzed in terms of share of premium in gross national product (Swiss Re, Sigma No. 2/2005, No. 5/2006, No. 4/2007, No. 3/2008, No. 3/2009). In the period between 2004 and 2008, Serbia held the 62nd position in the world, and comparing with the group in which it has been placed it can be concluded that Serbia has the satisfactory position since the countries like Romania and Turkey are behind Serbia. Switzerland has the highest percentage of share (with the tendency of decreasing the share), followed by Germany and Spain (Swiss Re, Sigma No. 2/2005, No. 5/2006, No. 4/2007, No. 3/2008, No. 3/2009).

The information about total number of insurance companies states that there were 26 insurance companies in the first quarter of 2010 (National Bank of Serbia, 2010). There are 22 companies involved into insurance affairs, and only four companies have re-insurance services included (Law on Insurance, The Official Gazette of 
the Republic of Serbia, 2004). Among companies dealing with insurance, there are seven companies involved in life insurance, nine companies working exclusively with non-life insurance, and there are six companies dealing with both life and non-life insurance. Breakdown by ownership shows that 19 insurance companies were in majority foreign and seven in majority domestic ownership as of 2009.

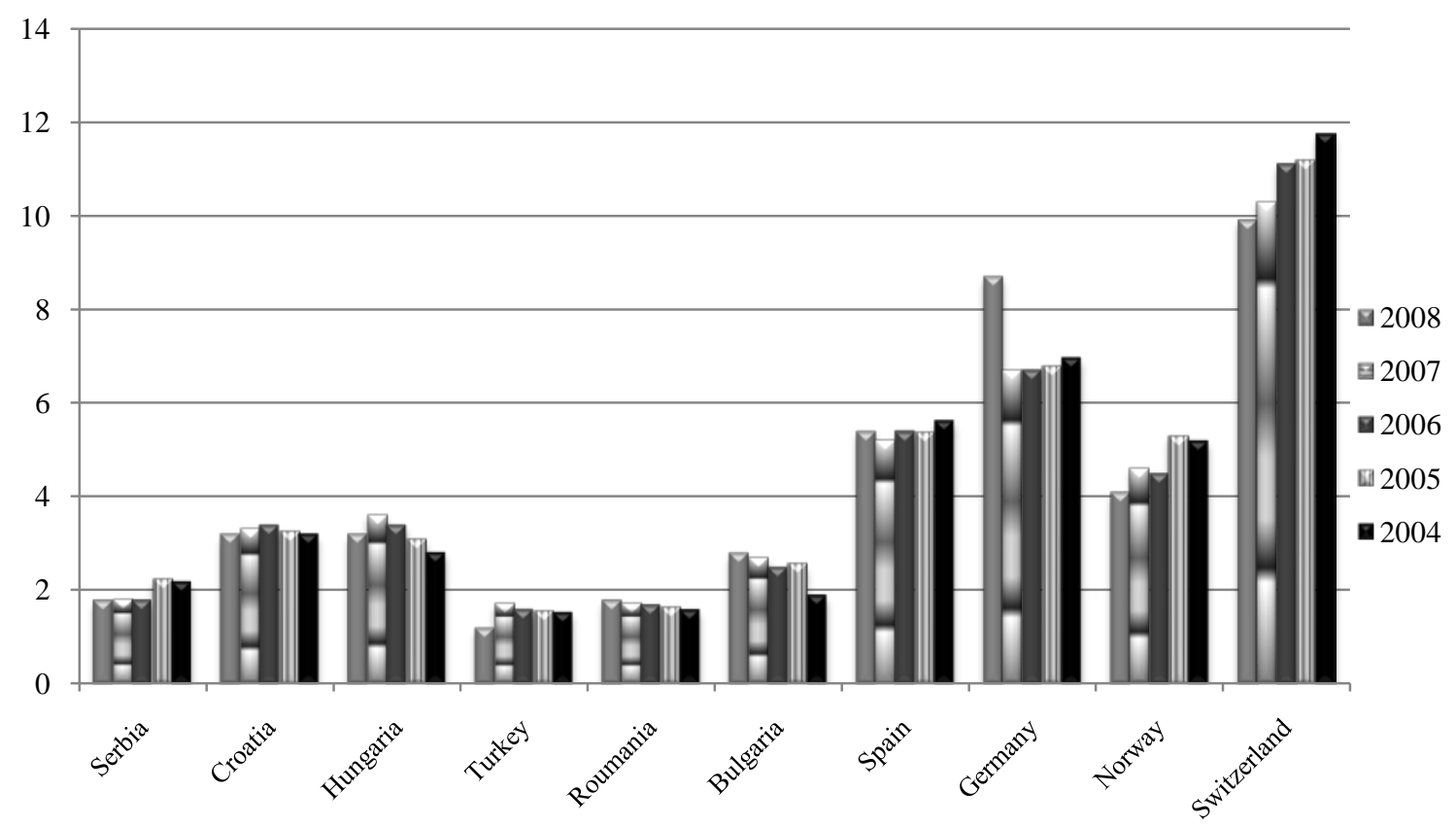

Figure 1. The level of development of insurance in some European countries: The share of premium in GNP.

The sector grew at a much slower pace (16.5\% in 2008 vs. 2.6\% in 2009), but its overall performance may be assessed as encouraging given the crisis environment. The total premium in 2007 ( $\$ 44.8$ billion) rose by 16.9\% compared to the premium in 2006, whereas the increase in the total premium in 2006 was $10.3 \%$ compared to 2005. If we observe the first quarters in the period between 2006 and 2010, the rise in premium can be noticed (16\%, 17.9\%, 1.09\%, and 2.41\% respectively). Observing the changes of total premium in the period from 2005 to the first quarter of 2010, it can be concluded that it had the tendency of rise, which is seen in Figure 2 (National Bank of Serbia, 2009).

Observing the premiums per capita in 2008 it can be seen in Figure 3 that Serbia holds 62nd position in the world with \$ 126.1, whereas the same indicator for EU-27 countries is \$ 3,061. The UK holds the first place with $\$ 6,858$, followed by the Netherlands with $\$ 6,849$ and Switzerland with $\$ 6,979.4$. Hungary and Croatia are in the 41st and 42nd position with the premiums per capita of \$ 501.4 and \$ 430.7 respectively, whereas Turkey holds the 65th position with $\$ 116.1$.

In the period between 2004 and 2008 Serbia on average holds the 65th position in the world with the decreasing tendency of premium per capita. Turkey holds the 61st position on average with the average premium per capita of \$ 115 in the given period. Hungary and Croatia hold on average the 38th and 41st position with the average premium per capita of \$ 398 and \$ 326 respectively. The Netherlands holds the 5th position with the average premium of $\$ 4,855$ per capita. The UK has the 1st place in the world, with the average premium of 
\$ 5,909 per capita (Swiss Re, Sigma No. 2/2005, No. 5/2006, No. 4/2007, No. 3/2008, No. 3/2009).

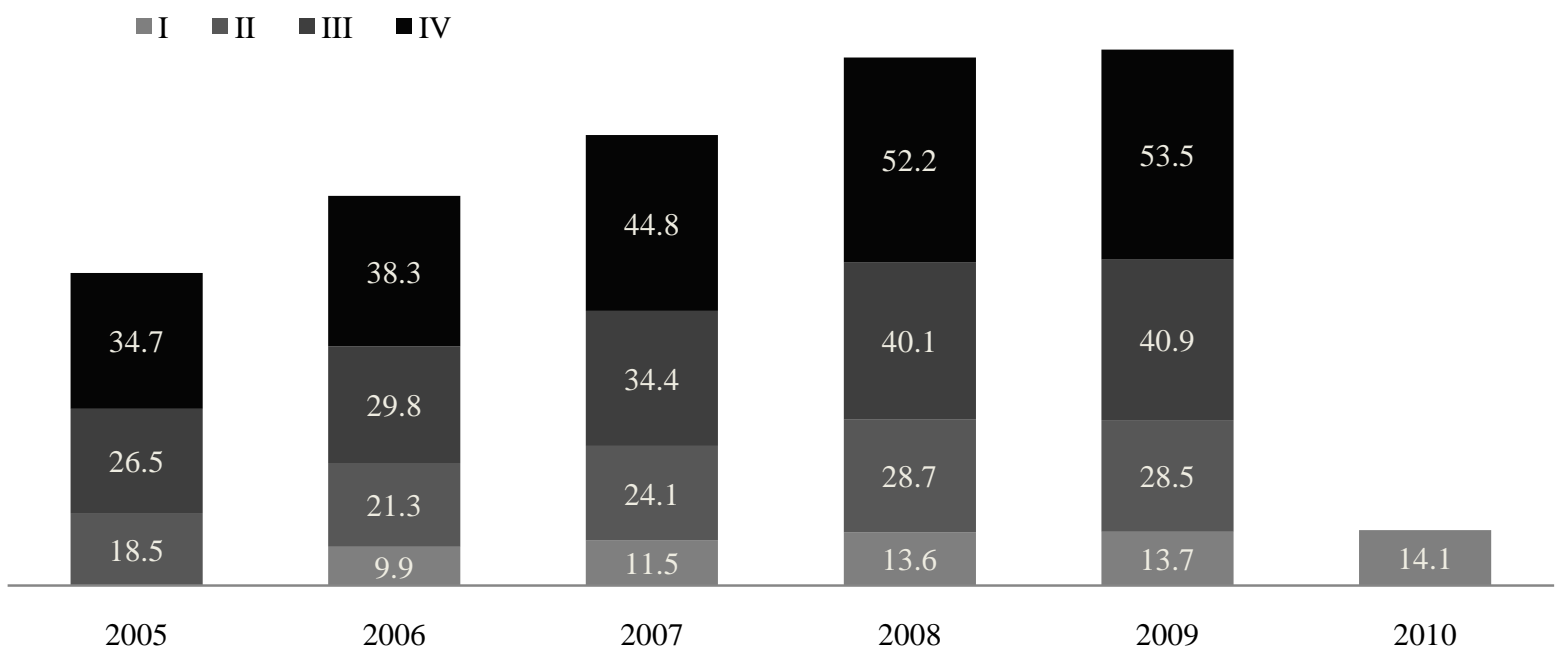

Figure 2. Quarterly movements in total premium (2005-2010) in billions of Serbian dinars (RSD).

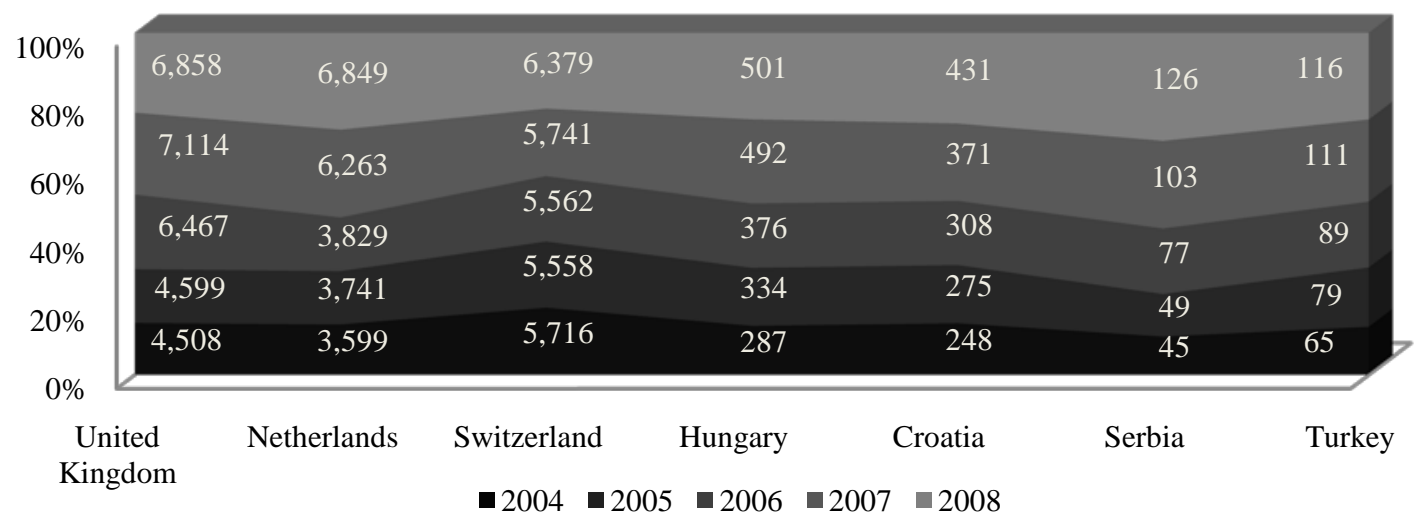

Figure 3. Premium per capita in European countries in dollars (2004-2008).

The development of insurance sector in its full potential would create a proper framework for appliance and use of other financial instruments such as financial derivatives.

\section{Options in the Function of Profitability Growth of Insurance Companies}

The main role of creating products is protection against risk, or reduction and elimination of harmful consequences of a financial risk. Traditionally, the public discourse on derivatives mentions hedging and speculative activities as complementary concepts. Modern approaches do not place hedging in the foreground but point out that derivative instruments are tools that should serve companies in a better assessment of financial risk, and they undoubtedly contribute to the possibility of generating higher profitability. Financial derivatives are controversial instruments for many reasons. First they are complex and thus seen as unclear to use, but where theorists and practitioners agree on is the fact that their use is subject to their full understanding; otherwise, the outcome is not certain. 
If we take into consideration the degree of development of domestic financial markets, there is an obvious significant lagging behind the international market of financial derivatives. During the last years, there has been removal of a number of factors critical for this lag in the development of domestic financial market, but the consequences of these factors still exist and can be felt. It is essential to have intense involvement of economy and banks in international financial markets in order to achieve the development of financial derivatives market in Serbia. Encounter between interest rates and exchange rates from foreign markets and local entities involved in these flows will result in risks from international financial environment.

In order to protect themselves against currency and interest rate risk, domestic entities must know of instruments, techniques and strategies of trading on uncertain foreign market derivatives. Positive legislation in the Republic of Serbia provides enough space for the development of this market, but so far important results have not been achieved in this segment. Experts say that there are many factors influencing the development of derivative markets in our country. The most important factors are as follows: faster development of spot financial markets, efficient protection of creditors' rights, active role of government in this segment, transformation of banks and economy and appropriate measures of monetary and fiscal policy. If the factors of development of derivative markets are rapidly implemented and brought into effect, dynamics of financial markets will be automatically more noticeable. There is no doubt that the current situation in our market cannot be compared with the situation that existed just a decade before. In fact, long-term credit instruments lacked in the market ten years ago, but today there are foreign currency savings bonds with long maturity, and the stock market is much better organized (Skakavac, 2008). A similar development path as in developed markets is expected and it will surely start with the classic futures forward contracts as the simplest financial derivative, but later more sophisticated financial instruments will occur, such as options, futures and swaps.

It is possible to predict that the market of financial derivatives in our country at an early stage in its development will have inter-bank character, with sporadic participation of some highly rated companies, whereas the share of the corporate sector and the citizens can be expected with the institutionalization of the clearing house and establishment of appropriate mechanisms to guarantee the performance of the contract.

A popular segment of the financial markets in the world is the market of financial derivatives. There are trade operations with derivatives such as futures, options, forwards and swaps. The basic function of derivative financial products is the protection from risk. The fact that applies to developed countries is that the number of investors trading with options tends to increase in contrast to the total number of investors. It is believed that there are significant opportunities to expand benefits and options for switching activity from over-the-counter market to stock market. The volume of options trading at CBOE is shown in Table 2 (Retrieved from www.cboe.com).

Table 2

The Volume of Options Trading at CBOE

\begin{tabular}{lrrr}
\hline & 2010 & 2009 & \multicolumn{1}{c}{2008} \\
\hline Shares & $572,688,137$ & $634,710,477$ & $604,024,956$ \\
Indexes & $269,989,511$ & $222,787,514$ & $259,499,726$ \\
Trading instruments & $276,362,700$ & $277,266,218$ & $329,830,388$ \\
Total & $1,119,040,348$ & $1,134,764,209$ & $1,193,355,070$ \\
\hline
\end{tabular}


Table 3

Global Options Markets

\begin{tabular}{|c|c|c|c|c|c|c|c|c|c|c|}
\hline \multirow[t]{2}{*}{ Exchange } & \multicolumn{2}{|c|}{$\begin{array}{c}\text { Volume traded } \\
\text { (Nber of Contracts) }\end{array}$} & \multicolumn{2}{|c|}{$\begin{array}{l}\text { Notional value } \\
\text { (USD millions) }\end{array}$} & \multicolumn{2}{|c|}{$\begin{array}{c}\text { Open interest } \\
\text { (Nber of Contracts) }\end{array}$} & \multicolumn{2}{|c|}{ Number of trades } & \multicolumn{2}{|c|}{$\begin{array}{l}\text { Option premium } \\
\text { (USD millions) }\end{array}$} \\
\hline & 2009 & 2008 & 2009 & 2008 & 2009 & 2008 & 2009 & 2008 & 2009 & 2008 \\
\hline \multicolumn{11}{|l|}{ Americas } \\
\hline BM\&FBOVESPA & $546,547,550$ & $350,046,283$ & 931,053 & 855,086 & $7,299,503$ & $2,847,679$ & $14,842,470$ & $11,877,646$ & 28,676 & 21,956 \\
\hline $\begin{array}{l}\text { Boston Options } \\
\text { Exchange (2) }\end{array}$ & $137,784,626$ & $177,600,467$ & 24,902 & 44,463 & NA & NA & $7,869,962$ & $9,544,517$ & 24,902 & 44,463 \\
\hline Buenos Aires SE & $25,132,711$ & $25,165,308$ & NA & NA & 747,190 & 344,528 & 535,375 & 578,555 & 241 & 339 \\
\hline $\begin{array}{l}\text { Chicago Board } \\
\text { Options Exchange } \\
\text { (CBOE) }\end{array}$ & $634,710,477$ & $604,024,956$ & $2,187,581$ & $2,717,661$ & $188,281,057$ & $187,131,615$ & $46,078,979$ & $35,461,401$ & 111,455 & 172,815 \\
\hline $\begin{array}{l}\text { International } \\
\text { Securities } \\
\text { Exchange (ISE) }\end{array}$ & $672,429,815$ & $687,165,942$ & NA & NA & NA & NA & $44,122,185$ & NA & NA & NA \\
\hline MexDer & 345,718 & 585,037 & 73 & 154 & 3,960 & 17,486 & 3,288 & 6,104 & NA & NA \\
\hline $\begin{array}{l}\text { Montréal } \\
\text { Exchange(1) }\end{array}$ & $14,507,261$ & $14,633,599$ & 76,246 & 73,732 & $1,547,120$ & $1,453,365$ & 839,596 & 765,794 & 2,060 & 3,182 \\
\hline $\begin{array}{l}\text { NASDAQ OMX } \\
\text { PHLX }\end{array}$ & $426,245,722$ & $537,954,692$ & NA & 225,858 & $193,253,211$ & $235,799,395$ & $23,782,783$ & $36,343,109$ & 123,339 & 225,859 \\
\hline NYSE Amex & $170,978,207$ & $121,342,636$ & NA & NA & NA & NA & NA & NA & NA & NA \\
\hline $\begin{array}{l}\text { NYSE Arca } \\
\text { Options } \\
\text { Asia Pacific }\end{array}$ & $273,769,123$ & $270,939,723$ & NA & NA & NA & NA & NA & NA & NA & NA \\
\hline $\begin{array}{l}\text { Australian } \\
\text { Securities } \\
\text { Exchange (Inc. } \\
\text { SFE) (4) }\end{array}$ & $15,242,798$ & $17,043,125$ & 196,892 & 262,171 & $1,451,359$ & $1,328,769$ & $1,460,904$ & $1,509,062$ & 23,405 & 32,629 \\
\hline $\begin{array}{l}\text { Hong Kong } \\
\text { Exchanges (1) }\end{array}$ & 41,863,995 & 48,038,651 & 127,339 & 168,772 & $3,836,130$ & $3,978,418$ & NA & NA & 9,623 & 16,419 \\
\hline Korea Exchange & 982 & 21 & 0 & 0 & 0 & 0 & 21 & 19 & 0 & 0 \\
\hline $\begin{array}{l}\text { National Stock } \\
\text { Exchange India }\end{array}$ & $14,066,778$ & $11,067,082$ & 88,173 & 50,851 & 41,012 & 153,609 & $10,928,922$ & $7,973,108$ & 2,998 & 1,860 \\
\hline $\begin{array}{l}\text { Osaka Securities } \\
\text { Exchange }\end{array}$ & 408,612 & 534,954 & NA & NA & 20,897 & 86,764 & 78 & 601 & 110 & 134 \\
\hline TAIFEX & $8,240,390$ & 872,880 & 14,824 & 5,319 & 2,584 & 574 & 110,547 & 29,666 & 19 & 13 \\
\hline $\begin{array}{l}\text { Tokyo Stock } \\
\text { Exchange Group } \\
\text { Europe, Africa, } \\
\text { Middle East }\end{array}$ & 660,875 & 88,256 & NA & NA & 102,789 & 44,628 & NA & NA & 46 & 4 \\
\hline $\begin{array}{l}\text { Athens Derivatives } \\
\text { Exchange (3) }\end{array}$ & 67,590 & 182,757 & 133 & 677 & 1,615 & 6,272 & 3,218 & 2,728 & 10 & 55 \\
\hline Borsa Italiana & $20,462,240$ & $20,056,426$ & 71,873 & 112,613 & $2,719,744$ & $2,748,370$ & 459,087 & 545,541 & NA & NA \\
\hline Eurex (1) & $146,286,451$ & $197,338,587$ & 353,285 & 881,388 & NA & NA & $2,822,091$ & $2,814,787$ & NA & NA \\
\hline Johannesburg SE & $15,670,869$ & $19,591,351$ & NA & NA & $2,814,565$ & $32,236,246$ & 6,960 & 9,079 & 984 & 1,346 \\
\hline $\operatorname{MEFF}(1)$ & $35,527,914$ & $18,317,249$ & 56,253 & 35,357 & $7,728,251$ & $4,669,410$ & 77,754 & 59,053 & 3,290 & 2,091 \\
\hline $\begin{array}{l}\text { NASDAQ OMX } \\
\text { Nordic Exchange }\end{array}$ & $28,775,091$ & $42,767,407$ & 399,648 & 47,388 & 3844093 & $4,913,148$ & NA & NA & 1,873 & 2,866 \\
\hline $\begin{array}{l}\text { NYSE Liffe } \\
\text { (European markets) } \\
\text { (1) (5) }\end{array}$ & $141,604,421$ & $142,684,583$ & 325,405 & 461,824 & $32,661,287$ & $33,374,165$ & $3,407,139$ & $3,676,891$ & $24,969,263$ & $39,222,710$ \\
\hline Oslo Børs & $2,219,926$ & $3,976,223$ & 1,493 & 5,377 & NA & NA & NA & NA & NA & NA \\
\hline Tel Aviv SE & 321,735 & 0 & 1,200 & 0 & 23,192 & 0 & 5,165 & 0 & 84 & 0 \\
\hline Wiener Börse & 474,69 & 848,021 & 596 & 3,946 & 70,363 & 78,631 & 14,290 & 17,510 & 55 & 163 \\
\hline Total & $3,374,346,574$ & 3,312,866,216 & & & & & & & & \\
\hline
\end{tabular}

The largest volume of trading in global markets is conducted in CBOE Stock Exchange, (which is shown in Table 3) with nearly one billion contracts in 2008 (Retrieved from www.world-exchanges.org), which is ahead of other Asian and European stock markets. CBOE also had the largest number of trade operations as 
well as the largest amount of premiums (Alijanović, Poklepović, \& Šego, 2009). The prerequisites for the survival of derivates market are transparency and regularity.

In order to provide the unique market at the level of the European Union, the latest framework for regulation is Solvency II. This act will be applied in Serbia in 2012. Solvency II acknowledges the influence of all risks that insurance companies face while determining the level of capital adequacy. For European insurers it is particularly significant that Solvency II regulations will enable long-term sustainability of the insurance sector as a whole, bearing in mind the key experience gained during the crisis. Solvency II will have a significant role in the field of determining the adequacy and efficient allocation of capital, which has a direct influence on the reduction of costs for the insured, better protection from failure because the capital is adapted to the appropriate risk and on the promotion of good examples of risk management (Swiss Re, Sigma No. 4/2006).

Global structure of balance sheet of insurance companies in Serbia is not stable. One of disadvantages of insurance companies is the fact that the value of fixed assets exceeds the value of working capital. Thus in 2008 and 2009 the value of fixed assets was about 35 and 41 billion dinars respectively, whereas the value of working capital was about 20 and 22 billion dinars. The relationship between fixed assets and capital are similar in 2007, 2006 and 2005 (30.1: 24.7 bn dinars, 24.9: 20.9 bn dinars and 22.5: 17.6 bn respectively). Immobile assets in the form of intangible assets show that it is difficult to make distinction between a non-insurance company and insurance company, or in other words, insurance companies recognize only those funds that are easy to be dealt with and are called approved funds. All these should be included in the balance sheets of insurance companies, whereas the permanent assets should be excluded from the balance sheet and thus property part of the balance sheet would be underrated (Ostojić, 2004). The above-mentioned problem and new institutional regional decisions make insurance companies transfer to property and life insurance by high capital census and strict division.

Despite the potential that financial derivatives (options) have, they are not used in the Republic of Serbia. The reason is that financial markets and financial institutions are at a low level of development and that financial derivatives still have only theoretical but not practical potential. The involvement in international financial flows would create the need for using the options, and thus there will be their contribution to profitability growth of appropriate insurance institutions.

\section{An Overview of Determinants of Profitability of Insurance Companies}

\section{Theoretical and Practical Framework of the Analysis of Profitability Indicators}

The National Bank of Serbia, as a regulatory body, set out six guidelines from the field of insurance, whose aim is to protect the interests of the insured and insurance beneficiary, create trust of citizens in financial and insurance sector in order to establish a safe and stable insurance market. These guidelines include different fields necessary for business operations, supervision, reporting and development of corporative managing of insurance companies. Their aim is to suggest a way of organizing and carrying out the business activities to insurers, so the efficiency can be improved.

The National Bank of Serbia created the guidelines (Carmel indicators) following IMF methodology so the performance assessment of insurance companies is not only standardized but simplified. They are criteria for quantitative monitoring and analysis of financial stability of insurance companies. The indicators of capital 
adequacy are the first to be applied in determining profitability of a certain insurance companies.

The analysis of indicators of capital adequacy shows how a certain insurance company is profitable. Determining capital adequacy according to Carmel methods consists of the following subgroups of indicators:

C1: Self-insured retention premium/Total capital. This indicator measures the relationship between self-insured retention premium and total capital of an insurance company. Self-insured retention premium is the approximation of risks considered in insurance contracts by insurance companies involved in non-life insurance. The significance of this premium is reflected in its capability to absorb inadequate price level of premiums and potential unexpected damage covered by insurance. More precisely, self-insured retention premium measures the insurance risk.

If the total value of this indicator is high, it can be concluded that the total capital is inadequate comparing to taking risks considered in insurance contracts (which is measured by the level of premium). Conversely, a low value after comparing self-insured retention premium and total capital brings to conclusion that capital resources are not used properly or that the insurance company has problems and it cannot generate its portfolio.

C2: Total capital reduced by loss/Total assets. This indicator measures the relationship between the total capital reduced by loss and total assets of the insurance company. This indicator measures the exposure of insurance company to market, investment and credit risk. The low value of this indicator may point out to the high exposure of the insurance company to these types of risks.

C3: Total capital reduced by loss/Technical reserve. If C3 indicator shows very high levels, there is inadequacy of total capital compared to take risks according to insurance contracts (measured by the level of technical reserve). The high level of indicators may signal a bad use of capital resources or failure to generate its portfolio.

An insurance company is obliged to determine, at the end of accounting period, the technical reserve for settling liabilities from insurance contracts (Law on Insurance “Official Gazette of RS”, No. 55/2004, 70/2004-red. and 61/2005.) and they serve for settling liabilities set forth in the issued insurance policies. Technical reserve is generated from the technical premium funds. Their level is determined by actuarial methods and it depends on future liabilities and structure of insurance portfolio.

In order to have more active insurance companies in financial market, there is an institutional framework provided where free financial funds can be placed. According to the Law on Insurance there is a clear picture what portion of technical reserve can be placed by insurance companies (Official Gazette of RS, No. 83/2005), but not to cause non-liquidity problems.

C4: Collateral reserve/Solvency margin. This indicator shows the relationship between collateral reserve and solvency margin. An insurance company in its business operations, i.e., settling its liabilities, does not use premium gains or placement from invested funds. The reason for that is the difference in business operations among insurance companies. That is why forming the reserve is necessary for the insurance companies. The reserve is formed by taking financial funds from gains, premium and start-up capital.

Collateral reserve is a form of guarantee that the insurance company will settle liabilities on the basis of insurance. It is the indicator of solvency. According to the Law on Insurance, collateral reserve must always be higher than the calculated solvency margin. An insurance company must have collateral reserve or capital in order to settle its liabilities. The insurance company is obliged to deposit and invest collateral reserve (Official 
Gazette of RS, No. 83/2005) in accordance with the insurance rules and good business customs. Likewise, the collateral reserve should be defined in the methods and amounts prescribed by the Law and with the aim of keeping and protecting its real value.

An insurance company must provide prescribed solvency margin. The solvency margin represents the quantitative indicator of solvency, i.e., the surplus of liquidity assets over the liabilities of the insurance company. The level of collateral liquidity must be higher than established solvency margin, i.e., its amount cannot be less than fixed assets. If there are variations, or in other words, if collateral reserve does not reach the amount of calculated solvency margin, the insurance company shall launch the harmonization programme within 30 days from the day of stating irregularities. Solvency margin is a guarantee that the liabilities of paying insured amount and indemnities will be settled in case the insurance company has financial problems. Solvency margin also represents the signal for supervisory board to take certain measures in case there are threats to solvency margin.

The analysis of profitability indicators brings to a clearer image of success of certain insurance companies. More detailed analysis of this indicator into parts refers to successful business operations of insurance companies. The necessary information is obtained from balance sheet, income statement and notes from financial reports as well as from consultations from the heads of insurance companies. The notes for 2009 and 2008 at the example of Dunav Insurance and DDOR Insurance will be presented hereinafter (see Table 4).

Table 4

Overview of Subgroups of Indicators for Dunav and DDOR Insurance

\begin{tabular}{llrc}
\hline \multirow{2}{*}{ Group } & Indicator & \multicolumn{2}{c}{ Amount in thousands } \\
\cline { 3 - 4 } & Self-insured retention premium/Total capital & 2009 & 2008 \\
\hline C2 & Total capital reduced by loss/Total assets & $122.1 \%$ & $11.1 \%$ \\
C3 & Total capital reduced by loss/Technical reserve & $40.9 \%$ & $40.7 \%$ \\
C4 & Collateral reserve/Solvency margin & $81.1 \%$ & $81.8 \%$ \\
\hline
\end{tabular}

By comprising the previously stated indicators of capital adequacy that have been practically applied, it can be concluded that there are signs of success, i.e., profitability of the insurance companies. Namely, by analyzing and interpretation of the capital adequacy indicators it is noticed that DDOR Insurance creates a lower level of profitability compared to Dunav Insurance.

\section{Conclusion}

A strong competition among the business entities participating in the market is more and more present in our region as well so the right observation and analysis of the business success is of paramount importance. The reason for that lies in the need for better understanding of the current position and better design of future business operations. Only companies that make right decisions are able to quick and efficient implement those decisions and they are characterized as successful companies.

In the first parts of papers, we attempted to show development of the insurance sector in the Republic of Serbia in comparison with other developed countries. Insurance is today one of the most profitable activities in the economies of European countries, and such tendency is seen in Serbia. The results of the research in the first part conclude that the insurance market in Serbia is among so-called developed markets with the chance to grow 
and be more prosperous. The conclusion of the National Bank of Serbia is that the insurance market and the level of its development are not at the satisfactory level. As indicators of the level of development of insurance market, in the first part of the paper are given the following: the share of the premium in gross national product in the period between 2004 and 2008, and here Serbia is on average at the 62nd position. Therefore it can be said that Serbia is at the satisfactory level since Romania and Turkey are behind according to this ranking. The movement of the total premium from 2005 to the first quarter of 2010 has been shown and it is seen that it had risen. The premium per capita for the period between 2004 and 2008 has been observed, and here Serbia holds 65th place in the world with rising tendency which is now \$ 80 on average. For example, Hungary and Croatia hold 38th and 41st place respectively with the average premium per capita of \$ 398 and \$ 326 respectively in the given period. Most reputable experts dealing with the analysis of business operations of insurance companies point out that Serbia will, after overcoming the financial crisis, have an increase in the insurance premium that will exceed the growth of the gross national product.

Developed financial markets show a tendency to increase the number of option contracts as well as other financial instruments. Through greater regulation and transparency of capital market in the Republic of Serbia, trading derivative securities, including options, should be introduced in the future and this introduction will be beneficial to the growth of profitability of insurance companies. Also the introduction of options on our stock exchange would be of great importance for capital market in Serbia because it would announce new possibilities for placing the funds.

The results of the research in the latter part of the paper point out that an insurance company may achieve and keep desirable level of profitability if it has an adequate level of capital. Transparency of business operations has been promoted since annual reports of insurance companies are available to the public on the Internet. It has been emphasized that this analysis is based on the indicators of CARMEL methods adapted to insurance companies. By this method it is possible to increase the extent of transparency and comparability because the National Bank of Serbia automatically takes all the indicators of CARMEL methodology into consideration. Within the analysis of profitability the indicator of capital adequacy has been used and it is undoubtedly the essence of today's business operations of insurance companies because its function is to absorb the risks, create security for the insured and provide the survival on the insurance market. The capital of insurance companies should satisfy internal capital requirements as well as the requirements of regulatory bodies or ranking agencies. The above-mentioned theoretical assumptions have been applied at the example of DDOR and Dunav Insurance.

Insurance companies thus will be able to utilize serious and scientifically based and practically proved ways and to fulfil their inclination towards successful business operations in comparison with their rivals—now and in the future.

\section{References}

Alijanović, Z., Poklepović, T., \& Šego, B. (2009). Trading with options on world markets. Računovodstvo i finansije, Zagreb, No. 10, 123.

Ikonić, D., Arsić, N., \& Milošević, S. (2011). Hedging with option as a contemporary concept and initiator of domicile financial market: The First International Symposium Engineering Management and Competitiveness. Zrenjanin, Republik of Serbia.

National Bank of Serbia. (2007). Annual Report.

National Bank of Serbia. (2009a). Total insurance premium by insurance companies and types of insurance.

National Bank of Serbia. (2009b). Annual Report. 
National Bank of Serbia. (2010). Insurance sector in Serbia-First quarter report.

Official Gazette of the Republic of Serbia. (2004). Law on insurance. No. 55/2004.

Official Gazette of the Republic of Serbia. (2005a). Decision on limiting certain forms of deposit and investing of technical reserve and on the highest amount of certain deposit and investing of collateral reserve of insurance companies. No. 83/2005.

Official Gazette of the Republic of Serbia. (2005b). Decision on methods for determining the level of solvency margin. No. $31 / 2005$

Ostojić, S. (2003). Applicative aspects of bank's financial reporting: Analytical framework of a single banking report. Privredna izgradnja, 1-2.

Ostojić, S. (2004). The necessity for restructuring insurance companies in Serbia. Privredna izgradnja, 1-2.

Paul, N., \& Bill, Y. (1999). A financial approach for determining capital adequacy and allocating capital for insurance companies. Bermuda: Hamilton.

Society of Actuars. (2004, March). Speciality guide on economic capital. Schaumburg: Illiniois.

Swiss, R. (2006). Solvency II: an integrated risk approach for European insurers. Sigma No. 4/2006.

Žarković, N. (2009). Insurance in the world and Serbia under the conditions of economic crisis. Tržište, Novac, Kapital Journal, Chamber of Commerce of Serbia, Belgrade. 